\title{
BECKFORD AND BEYOND. SOME DEVELOPMENTS IN THE DOCTRINE OF ABUSE OF PROCESS.
}

\section{Judge Richard Bray*}

In recent years one of the largest growth areas of law in the criminal trial jurisdiction has been the development of the doctrine of abuse of process.

As recently as the 1970s, submissions based on abuse of process were virtually unknown in the criminal courts. Now there is no competent defence advocate who does not come to court well armed with a quiver full of authorities ready to shoot down a prosecution as the opportunity arises.

The underlying principle behind the doctrine of abuse of process is the concept that the court has a duty in criminal cases, to hold the balance between the interests of the state in maintaining order and the rights of individuals, and in exercising that duty the court retains a residual power to stay prosecutions which are vexatious or oppressive.

The leading cases almost always re-iterate the principle that such a power should very rarely be exercised. ${ }^{1}$ Despite such dicta there has been an inexorable rise in the number of cases in which the courts have intervened on the basis of abuse of process, and distinct categories of abuse cases have developed.

The reasons behind this development may be disputed and could indeed form the basis of a separate dissertation. Some cynics may say that it coincides with the emergence of the CPS as the prosecuting authority. They would argue that with the advent of bureaucracy have come all the incidental failings that are associated with it: loss of individual responsibility, the blind following of guidelines rather than the individual exercise of judgment, delays, lack of liaison between police and prosecution leading to failures of disclosure and loss of evidence. Others would argue that in the fight against ever more sophisticated crime the police have responded with increasingly intrusive methods of surveillance and detection, which threaten individual liberty.

In any event, the categories into which most abuse of process applications are generally divided may be said to speak for themselves: misuse of the process of court, misconduct by the prosecution or police, failures in the disclosure of evidence, delay in the trial process.

\footnotetext{
${ }^{*}$ His Honour Judge Bray sits on the Midland Circuit.

${ }^{1}$ See for example dicta of Lord Salmon in DPP v Humphreys [1977] 1 HL p 46 C-F and dicta of Lord Lane in Att Gen Ref No 1 of 1990 (1992) 95 Cr App R p302.
} 
The aim of this article is to revisit the underlying principles which the courts apply in considering these applications, to review some of the developments in the doctrine that have evolved in recent cases and to reemphasise the importance of judicial discretion in this field.

The doctrine of abuse of process is based on common law and judicial precedent. The oft-quoted test is 1) whether the defendant can have a fair trial and/or 2) whether the defendant can fairly be tried $R v$ Beckford. ${ }^{2}$

During submissions reliance is sometimes placed on Article 6 of the Human Rights Act and Section 78 of PACE. ${ }^{3}$ But in practice these add nothing to common law principles because they are both based on the same concept of fairness. Under Article 6 a defendant is entitled to a "fair and public hearing within a reasonable time". Under Section 78 a court may refuse to admit evidence "if it appears to the court having regard to all the circumstances, including the circumstances in which the evidence was obtained, that the admission of the evidence would have an adverse effect on the fairness of proceedings". Both provisions are drafted in the widest terms, thus leaving it to the judge to decide what is fair and just in the individual circumstances of each case.

It follows that the doctrine has been able to develop piecemeal from case to case to meet pressures and circumstances as they arise, hence the ever widening field of use. The categories are never closed.

Before turning to recent developments and to some of the important issues that arise it is useful, perhaps, to set out the brief background.

The starting point can be said to be Connolly $v$ DPP. ${ }^{4}$ It was the custom in those days, where the charge was murder, for the prosecution not to include any other count on the indictment. In that case the defendant had been acquitted, on appeal, of murder and manslaughter where a victim had been killed in a robbery. The prosecution subsequently pursued a charge of robbery on a second indictment. The defendant appealed his conviction inter alia upon the ground that the second trial, upon essentially the same facts, should have been stayed as an abuse of process. The Court of Appeal dismissed the appeal upon the ground that it had not been open to the jury on the first indictment to convict the defendant of robbery.

Lord Devlin, in his judgment, reviewed the case of Downes ${ }^{5}$ in which Lord Goddard had set out the four grounds on which an indictment could be

${ }_{3}^{2}$ [1996] 1 Cr App R 94.

3 For example $R v$ Khan [1997] AC 558 (improper police conduct), $R v$ Looseley [2002] 1 Cr App R 29 (entrapment), Att Gen Ref No 2 of 2001 [2004] 2 WLR 1 HL (delay), Sofris v $S$ [2004] Crim L R 846 (loss of evidence).

${ }_{5}^{4}$ [1996] 1 Cr App R 94.

5 [1954] 37 Cr App R 148. 
quashed or stayed namely (1) where it is held defective in substance or form (2) where a plea in bar is resolved in favour of the defendant (3) where a nolle prosequi is entered by the prosecution and (4) where the indictment discloses an offence which the court has no jurisdiction to try. Lord Devlin added a fifth ground namely where the criminal proceedings constitute an abuse of the court's process.

In the judgments of the House of Lords it was accepted that the court had a general and inherent power to protect its process from abuse. This case was considered by the House of Lords in DPP v Humphreys ${ }^{6}$ where Lord Salmon said: 'It is only if the prosecution amounts to an abuse of the process of the court and is oppressive and vexatious that the judge has the power to intervene. Fortunately such prosecutions are hardly ever brought but the power of the court to prevent them is, in my view, of great constitutional importance and should be jealously preserved'.

That last sentence, spoken in 1977, shows how rarely the doctrine of abuse was invoked some thirty years ago. It has now blossomed into a number of distinct categories, all governed by the principles set out in Beckford's case. Within the scope of this article it is only possible to highlight some of the developments in the major categories. All, however, are concerned with the need to strike the balance between the right of the individual to a fair trial and the interest of the state in seeing that wrongdoers are convicted. As the cases cited below will show, it is possible to disagree with some of the judgments made but it must surely remain a fundamental principle that this balance must be struck by the courts and an independent judiciary. This is particularly important because, as the cases considered below will show, the majority of abuse of process applications are concerned with abuse of the criminal process by government bodies. It is the duty of the courts, applying the rule of law, to control the misuse of power by the executive. As Lord Denning used to put it "Be you ever so high, the law is always above you". It is a sad reflection of the times and of interference by government that this principle has been questioned and needs to be reasserted.

\section{MISUSE OF THE PROCESS OF COURT}

Two main strands can be identified in this category. Firstly, where the prosecution seek to try a defendant twice upon the same essential facts, and secondly, where they seek to resile from a promise or representation that the defendant would not be prosecuted.

Under the first heading the principle is that no one should be punished twice for an offence arising out of the same or substantially the same set of

${ }^{6}$ [1977] AC HL. 
facts. Thus in $R v$ Moxon - Tritsch $^{7}$ a private prosecution for causing death by reckless driving was stayed after a defendant had been convicted of careless driving and excess alcohol offences.

In $R v$ Beedie $^{8}$ a prosecution for manslaughter arising out of a defective gas installation was stayed where the defendant had already pleaded guilty to summary offences arising out of the same incident.

In $R v$ Horsham $J J$ ex $p$ Reeves $^{9}$ it was held that it would be vexatious and oppressive to permit the prosecution to pursue charges which were essentially the same as those on which the justices had found no case to answer in committal proceedings.

A typical example of this type of case arose in $R v$ McFee. ${ }^{10}$ The police were chasing a car suspected of being involved in a robbery. The car was stolen and being driven dangerously in the chase. When the police caught up with it, various occupants decamped and ran away leaving the defendant in the driving seat. He was arrested and later that day he appeared in the magistrates' court. The CPS accepted a plea to the lesser offence of being carried in a stolen vehicle. During the chase the car had been caught on a speed camera. The police recovered the film from the camera and the defendant was identified by an officer as being the driver shown on the film. The film was in the hands of the police at the time of the magistrates' court case but had not been developed. After the defendant had been sentenced for the lesser alternative offence the CPS later sought to prosecute him for dangerous driving and driving whilst disqualified, claiming that fresh evidence was now available.

The prosecution was stayed on the ground that it was based on the same set of facts. The prosecution had accepted the defendant's plea on the basis that he was a passenger in the car, they had not sought an adjournment to analyse the further evidence and they were therefore bound by their earlier decision. To have allowed the prosecution to proceed, after an earlier prosecution had concluded, would have opened the door to further prosecutions whenever fresh evidence emerged.

In the recent case of $R v L^{11}$ the long-standing issue of whether a criminal court is bound by a previous decision on the same facts in a civil court has at last been resolved. The appellant was convicted of the manslaughter of his 3 month old baby. In previous care proceedings the judge had concluded that it was not possible to determine which of the two parents had caused the injuries. It was submitted that in the light of the ruling in the care proceedings

\footnotetext{
${ }^{7}$ [1988] Crim L R 46.

8 [1997] 2Cr App R 167.

975 Cr App R 236.

${ }^{10}$ Northampton Crown Court Aug $31^{\text {st }} 2006$ unreported.

${ }^{11}$ [2006] EWCA Crim 1902.
} 
the prosecution should have been stayed. The appeal was dismissed. It was held that the civil court had no jurisdiction finally to exonerate or condemn the appellant or to pass sentence on him and was not therefore 'competent' for that purpose.

Under the second heading there is a clutch of cases relating to the revival of prosecutions after promises or representations that the defendant would not be prosecuted. For example in $R v$ Croydon Justices ex parte Dean ${ }^{12}$ a defendant had been arrested as part of a murder investigation. He had not taken part in the killing but had assisted in destroying the victim's car. In interview he gave vital information to the police about the killing. The police decided to treat him as a prosecution witness and gave him a promise that he would not be prosecuted. The CPS later sought to prosecute him for the destruction of evidence. The Divisional Court held that the prosecution by the CPS of a defendant who has been given a promise of immunity by the police, albeit informally, is capable of being an abuse of process. In the particular circumstances of this case, where the defendant had clearly given assistance to the police in response to the promise, the prosecution should be stayed. However, after some uncertainty as to whether such promises provided an ultimate bar to further prosecution the issue appeared to be resolved in $R v$ Horseferry Road Magistrates' Court ex parte DPP. ${ }^{13}$ The Divisional Court quashed a stay for abuse of process holding that the breach of an assurance not to prosecute cannot per se justify a stay. The court must consider whether the defendant has suffered such prejudice from the pursuit of proceedings, e.g. by delay, as to justify a stay.

Thus, in $R v$ Pepperman, ${ }^{14}$ a doctor was charged with indecently assaulting two separate patients. After investigating the first alleged assault the police had informed the defendant's solicitors that he would not be prosecuted. Six years later, following a second complaint by a different patient, the CPS decided to prosecute both alleged offences. The judge dismissed the application to stay the count in relation to the first offence holding that the promise could not ipso facto justify the stay and that in the circumstances the defendant had not suffered such prejudice as a result of delay that he could not have a fair trial.

The recent House of Lords decision in Jones $v$ Whalley ${ }^{15}$ has not, it must be said, helped to clarify the position. In that case the appellant had been cautioned for assault on the respondent. He had signed a written form of caution which contained the words: 'This means that you will not have to go before a criminal court in connection with this matter but that a record will be

\footnotetext{
${ }^{12}$ (1994) 98 Cr App R 76.

13 [1999] COD 441.

${ }^{14}$ Northampton Crown Court Dec $4^{\text {th }} 2006$ unreported.

15 [2006] UKHL 41.
} 


\section{BECKFORD AND BEYOND}

kept of this warning'. The respondent subsequently brought a private prosecution. The justices stayed the prosecution for abuse of process. The Divisional Court reversed the decision. The House of Lords allowed the appeal. They cited with approval the judgment of the Divisional Court in $R v$ Croydon Justices and found that the particular terms of the caution amounted to a representation that he would not be prosecuted.

The House of Lords had been asked to rule on the wider issue whether, when a person is cautioned or told that he will not be prosecuted, that must always be a bar to a subsequent prosecution. Although they expressed sympathy for this view, certainly in the case of subsequent private prosecutions, they declined to give a ruling without further argument before them.

Although citing $R v$ Croydon Justices it appears that the House of Lords was not referred to and did not consider, the judgment in $R v$ Horseferry Road Magistrates' Court. It must now be uncertain to what extent that case remains good law.

\section{ENTRAPMENT AND POLICE MISCONDUCT}

Faced with the growing sophistication of criminals, particularly in the field of drugs, the police have resorted to intrusive and unconventional methods of crime detection and investigation including the use of bugging techniques and undercover police officers. The boundary between acceptable and unacceptable police behaviour has become increasingly blurred and abuse of process applications have been used to test the reaction of the courts. ${ }^{16}$

There is a distinction to be made between 'entrapment' cases where the abuse argument is based on the submission that the police have provoked the

${ }^{16}$ Examples are: Nottingham City Council v Amin [2000] 1 Cr App R 426 (police officers, posing as fares, hail an unlicensed taxi), Christou v Wright (1992) $95 \mathrm{Cr}$ App R 264 (undercover police officers set up a jewellery shop in London, posing as shady jewellers ready to buy stolen goods), $R$ v Smurthwaite (1994) 98 Cr App R 437 (undercover police officer poses as contract killer to a man who wanted to kill his wife), $R v$ Gill [1989] Cr L R 358 (undercover police officers pose as IRA members willing to carry out a shooting for money), $R v$ Williams (1994) $98 \mathrm{Cr}$ App R 209 (police leave unattended van in busy high street full of 'cigarette cartons'), $R v$ Khan [1997] AC 558 (police leave a bugging device in a private house), $R v$ Bailey [2001] EWCA 733 (undercover police officers trick their way into a house posing as purchasers of stolen goods), $R v$ Grant [2005] EWCA 1089 (police fix bugging devices in a police station to record private interviews between defendants and their solicitors), $R$ v Marshall and others, Leicester Crown Court Nov 2005 unreported, (police officer acts as lorry driver importing heroin for drugs gang). 
defendant into committing an offence which he would not otherwise have committed, and cases of improper conduct where the police have used improper methods to obtain evidence relating to an offence which was not prompted by the police.

In the "entrapment" cases it is said that a stay will normally be the appropriate remedy. In improper conduct cases an application should normally be made for the exclusion of evidence under Section 78. In some cases, as we shall see, this distinction has become blurred.

\section{(1) Entrapment}

The leading case is still $R v$ Looseley: ${ }^{17}$

The only proper purpose of police participation is to obtain evidence of criminal acts which they suspect someone is about to commit or in which he is already engaged. It is not to tempt people to commit crimes in order to expose their bad characters and punish them (per Lord Hoffman).

The judgment followed dicta of Bingham LJ in Nottingham City Councilv $\mathrm{Amin}^{18}$ in which he held that where the police had done no more than present the defendant with an unexceptional opportunity to commit crime they were not to be regarded as having instigated or incited an offence.

Dicta in these cases have been used to justify test purchases by undercover police officers, nowadays the standard method of catching drugs offenders on housing estates. Under cover of such authorities the police have adopted increasingly bold tactics.

A classic example is the recent case of $R v$ Harmes and Crane ${ }^{19}$ where undercover police officers supplied soft drinks to a pub landlord suspected of drug smuggling. The officers asked to be paid in cocaine. This encouraged the defendants to set up a conspiracy importing drugs by plane into Heathrow, involving the officers. Despite the fact that there were numerous breaches of the police Codes of Practice under RIPA and the fact that it was the officers who first brought up the question of cocaine, the Court of Appeal upheld the judge's ruling that the defendants had not been induced to commit crime but had taken advantage of the opportunity to participate in drugs smuggling for their own individual gain.

\footnotetext{
${ }^{17}$ Att Gen Ref (No 3 of 2000) [2002]1 Cr App R 29.

${ }^{18}$ [2000] 1 Cr App R 426.

19 [2006] EWCA Crim 928.
} 
A case on the other side of the coin is $R v$ Moon. ${ }^{20}$ The appellant, a heroin addict, had been persuaded by an undercover woman police officer to supply her with a small amount of heroin. The Court of Appeal held that the prosecution should have been stayed for abuse of process. This case might seem to give some encouragement to a challenge to the validity of test purchase operations. It is best seen as a decision on its own facts. The court found, on the admission of the prosecution at trial, that the defendant was a drug user rather than a supplier and had been pressed into supply by a sob story told by the undercover police officer. It can be said therefore that the court was not seeking to disagree with the dicta in Amin but merely to suggest that where a mere drug user was caught in the net of a police undercover operation the appropriate charge was possession rather than supply.

\section{(2) Improper Conduct}

In these cases a balance has to be struck between the public interest in "ensuring that those charged with grave crimes should be tried and the competing interest in not conveying the impression that the end justifies the means". ${ }^{21}$

Many of the cases involve bugging by police officers of premises occupied or frequented by defendants, often in breach of police codes of practice. In abuse of process applications reliance is often placed on Article 8 of the Human Rights Act and the consequential breach of the right to fair trial under Article 6. Article 8 provides that:

(1) Everyone has the right to respect of his private and family life, his home and his correspondence.

(2) There shall be no interference by a public authority with the exercise of this right except such as is in accordance with the law and is necessary in a democratic society in the interests of national security, public safety......for the prevention of disorder or crime.

A leading case is $R v$ Khan. ${ }^{22}$ A bugging device had been fixed to the outside of a private house without the knowledge of the occupiers. The House of Lords held that the bugging involved a breach of Article 8 of the Human Rights Act but that the evidence thereby obtained was fairly admitted within the provisions of Section 78 of PACE. Lord Nolan's judgment was trenchant:

${ }^{20}$ [2004] EWCA Crim 2872.

${ }^{21} R v$ Latif and Shahzad [1996] 2 Cr App R 92.

22 [1997] AC 558. 
"If the behaviour of the police in the particular case amounts to an apparent or probable breach of some relevant law or convention, common sense dictates that this is a consideration which may be taken into account for what it is worth. Its significance, however, will normally be determined not so much by its apparent unlawfulness or irregularity as upon its effect, taken as a whole, upon the fairness or unfairness of proceedings. The fact that the behaviour of the police constitutes a breach of the convention or of a foreign law can plainly be of no greater significance per se than if it constituted a breach of English law.' And he went on that he had reached his conclusion in the case: 'not only firmly as a matter of law but also with relief. It would be a strange reflection on our law if a man who has admitted his participation in the alleged importation of a large quantity of heroin should have his conviction set aside on the grounds that his privacy has been invaded."'

This case was followed by the Court of Appeal in $R v$ Bailey. $^{23}$ Undercover police officers had tricked their way into a house by posing as purchasers of stolen goods. They had with them recording equipment and recorded admissions by the defendants of drug dealing and offers to sell drugs. The Court of Appeal (per Judge LJ) held that there had been no breach of Article 8 since the recording equipment had not been fixed or left within the home and that the evidence could fairly be admitted since it was the best possible evidence of what had actually been said.

The ruling in Khan was endorsed by the European Court of Human Rights holding that the admission of evidence obtained in breach of Article 8 did not necessarily render the proceedings unfair. It was for the domestic courts, in accordance with their rules of evidence to decide what evidence it was fair to admit. The Court therefore endorsed the exercise of the judge's discretion to decide what was fair in each individual case.

These two cases represent a high-water mark of judicial approval for the use of invasive techniques on the part of the police. Effectively, the courts were prepared to admit the evidence, even though somewhat dubiously obtained, upon the basis it was highly probative of guilt, and therefore just to admit it. 
However, the case of $R v$ Grant $^{24}$ may represent some turning back of the tide. This was one of three cases involving Lincoln police officers who had placed bugging devices in the exercise yard of a police station thus allowing communications between defendants and their solicitors to be captured. In two cases the prosecution had been stayed as an abuse of process, but in the third Astill $\mathrm{J}$ had refused the application. The Court of Appeal allowed the appeal against conviction, finding that the prosecution should have been stayed even though nothing was recovered from the illicit intercepts of any value to the prosecution and nothing so recovered was used as, or led towards, any evidence to be called by the Crown.

Much of the leading judgment of Laws LJ was taken up with a critical assessment of Astill J's finding of fact that the bugging had not been a deliberate violation of the right to professional privilege. It was taken as axiomatic that deliberate misconduct of this kind was sufficient to require a stay. Laws LJ said: 'We are in no doubt that in general unlawful acts of the kind done in this case, amounting to a deliberate violation of a person's right to legal professional privilege, are so great an affront to the integrity of the justice system, and therefore the rule of law, that the associated prosecution is rendered abusive and ought not to be countenanced by the court'. He went on:

"It is unnecessary to multiply authority to demonstrate the importance which the law attaches to professional privilege .....' 'Where the court is faced with illegal conduct by police or state prosecutors which is so grave as to threaten or undermine the rule of law itself, the court may readily conclude that it will not tolerate, far less endorse, such a state of affairs and so hold that its duty is to stop the case."

In support of this proposition he quoted the case of $R v$ Horseferry $R d$ Magistrates Court Ex p. Bennett. ${ }^{25}$ In that case a defendant had been brought to this country to stand trial as a result of the collaboration of authorities here and abroad in disregard of extradition procedures. It was held that the prosecution should be stayed regardless of the merits of the case.

Bennett's case can surely be distinguished from Grant on the basis that the trial proceedings were vitiated ab initio by the illegality of the extradition, whereas in Grant the arrest and charging of the defendant were legal. It was merely that improper attempts had been made to acquire further evidence against him. It may be that the decision in Grant can be justified upon the basis that there are some cases of misconduct which are so extreme that to 
proceed would be an affront to the administration of justice. But it may also be suggested that the decision in this case fits uneasily with the principles set out by the House of Lords in Khan and the balancing exercise in Latif.

Grant was a serious case of murder involving an allegation of contract killing, which needed in the interests of justice to be tried. If there had been any evidence against the defendant obtained by the illegal bugging it could have been excluded under S.78, which is the normal remedy in such cases. In Grant there was no evidence obtained by the bugging and therefore no prejudice suffered by the defendant so as to render his trial unfair. The trial should therefore have been allowed to proceed leaving the police officers to be disciplined or even prosecuted at a later stage as deemed appropriate.

Grant's case may also be seen to be inconsistent with the approach of the Court of Appeal in $R v$ Heston- Francois ${ }^{26}$ which was cited with approval by Lord Lane in Att Gen Ref No 1 of $1990 .{ }^{27}$ In that case the police searched under warrant the defendant's home for stolen jewellery. They removed files of documents and tapes prepared for his defence to charges of burglary. The officer showed the documents to prosecution witnesses. The judge refused to stay the indictment. On appeal Watkins LJ said:

" The facts of the present case demonstrated the importance of, among other things, discovering during the trial whether the alleged misconduct by the police had any effect upon the evidence and any likely bearing on the result. It had none'. Later on he said: 'However reprehensible conduct of this kind may be, it is not, at least in circumstances such as the present, an abuse or, in another word, a misuse of the court's process. It is conduct which in these circumstances falls to be dealt with in the trial itself by judicial control upon admissibility of evidence...Applying that test to the facts in Grant, the prosecution of the defendant was surely not 'a misuse of the court's process'. The trial judge could fairly control proceedings by exercising his discretion to exclude evidence where appropriate."

Although there may be argument in individual cases as to where the courts should draw the line in striking the balance between the need to prosecute grave crimes and the need to restrain oppressive and improper behaviour by prosecuting authorities, there can surely be no argument that this duty must lie 


\section{BECKFORD AND BEYOND}

with the courts since the courts can be the only effective restraining influence on the executive.

This "balance" is continually under tension, as exemplified by the uneasy relationship between the courts and the Home Office in recent years as a result of what may be seen as constant legislative interference by successive governments in the criminal justice system.

A small but significant example of this is the proposed government legislation to curtail the powers of the Court of Appeal so that it will no longer be able to quash convictions "on purely procedural grounds" in cases where it is sure that the defendant is factually guilty. This proposal is in practice an attempt to prevent the courts from exercising their residual power to restrain prosecutions which are an abuse of the court's process, a power which Lord Salmon in DPP $v$ Humphreys declared to be "of great constitutional importance and should be jealousy preserved."

The proposal has come under scathing attack from Professor Spencer in his recent article: "Quashing convictions, and squashing the Court of Appeal". ${ }^{28} \mathrm{He}$ points out that under such provisions the decision in $R v$ Horseferry Rd Magistrates ex parte Bennett could no longer be maintained. He argues that the fact that two views are possible about some of the cases in which the higher courts felt it necessary to quash the conviction of an obviously guilty person is no good reason for abolishing their power to do so altogether. He goes on to say that:

"decisions of this sort are best made as they are now: by our senior judges, after argument, on a case by case basis. There is no reason to tie their hands with yet more prescriptive legislation, passed with an eye to reversing particular decisions that happen to have attracted the eye of the tabloid newspapers." 29

\section{DELAY}

Applications in this category have become increasingly common because of the increase in the numbers of prosecutions for sexual offences which arise out of allegations of historic abuse and which the CPS are prepared to prosecute in apparent disregard of the $50 \%$ chance of success guideline.

The standard test was set out by Lane LCJ in Att Gen Ref No 1 of $1990 .^{30}$ Two questions had been posed in the reference: (1) whether proceedings on

\footnotetext{
28 [2006] Vol 170 JP 790.

29 [2006] Vol 170 JP 793.

30 (1992) 95 Cr App R 296.
} 
indictment may be stayed on the ground of prejudice arising from delay in the institution of those proceedings even though that delay has not been occasioned by any fault on the part of the prosecution and (2) what is the degree of likelihood and the seriousness of any prejudice which is required to justify a stay of such proceedings.

Lord Lane noted with some unease that the earlier rule which required that delay should be unjustifiable seemed to have been relaxed in recent cases. He therefore felt constrained to agree 'to a limited extent' that mere delay without fault which gave rise to prejudice could amount to an abuse. However he went on to say: "Stays imposed on the grounds of delay or for any other reason should only be employed in exceptional circumstances." On the second question he said: "no stay should be imposed unless the defendant shows on a balance of probabilities that owing to the delay he will suffer serious prejudice to the extent that no fair trial can be held." Lord Lane went on to express the hope that "this judgment will result in a significant reduction in the number of applications to stay proceedings on the ground of delay."

That hope remains unfulfilled. The flood of applications since has shown no sign of decreasing. Indeed recent decisions of the Court of Appeal have thrown into doubt such fundamental issues as the appropriate method of procedure in abuse applications, the test to be applied in considering an appeal against conviction, and even the prejudice test set out by Lord Lane in Att Gen Ref No 1 of 1990.

In $R v B^{31}$ there had been a 30 year delay in making a complaint of sexual abuse. The Court of Appeal, presided over by Lord Woolf CJ, found that the judge had been right to refuse the application to stay, made at the start of the trial. Moreover, they found that no criticism could be made of the conduct of the trial or of the judge's summing up or his direction to the jury on the subject of delay. Nevertheless they allowed the appeal on the basis that the Court of Appeal had a residual discretion to set aside a conviction if it was felt to be unsafe or unfair. The basis for the exercise of the discretion appears at paragraph 28 of the judgment:

"It has to be recognised because of the delay that occurred, in our judgment the appellant was put in an impossible position to defend himself. He was not able to conduct any proper cross-examination of the complainant. There was no material he could put to the complainant to suggest that she had said something had happened on one occasion which could be established to be incorrect. All that the appellant could do

${ }^{31}$ [2003] EWCA Crim 319. 


\section{BECKFORD AND BEYOND}

was to say that he had not committed the acts alleged against him."

Not surprisingly the decision in this case was relied upon in subsequent appeals based on substantial delay in the making of a complaint.

In $R v E^{32}$ the Court of Appeal was able to distinguish $R v B$ upon the basis that in the later case there was some supporting evidence for the claimant's allegations and material which the complainant could be crossexamined upon. In his judgment Hooper LJ felt constrained to make two criticisms of the judgment of Lord Woolf in $R v B$. First he pointed out what he described as a "degree of tension" between Lord Woolf"s assertion that the trial judge had been right to refuse a stay and right to allow the case to go to the jury for a verdict after the evidence and the Court of Appeal's own decision that the evidence was unsafe. As Lord Hooper pointed out "it is questionable that the judge was right to conclude at the close of the evidence that it would not have been unsafe for the jury to convict the defendant if it had been impossible for the defendant to defend himself."

Secondly, Lord Hooper criticised the concept of 'residual discretion' as a ground for quashing a conviction. As he crisply put it: "We remind ourselves that if the court concludes that the conviction is unsafe, it must be set aside. We approach this appeal in that way."

During the course of his judgment in $R v B$ Lord Woolf expressed the view that the trial judge should not entertain applications to stay made on the basis of delay until the end of the evidence. ${ }^{33}$ He repeated this view in $R v$ Smolenski $i^{34}$ where he again found that the conviction was unsafe even though the judge had been right to leave the case to the jury. He stated that applications to stay for abuse of process should be discouraged in cases of this type where it was sometimes very difficult for children to speak out and where it could take many years before matters came to light. Where evidence was given after many years had passed by, trial judges should exercise very careful scrutiny at the end of the evidence to determine whether cases were safe to be left to juries.

If this is intended to be a direction to trial judges to hear applications to stay only after the evidence has been heard, it is open to obvious objections. Firstly, the judge would have to determine the issue whether the defendant could have a fair trial at a time when the trial itself had substantially already taken place, with all the attendant strain upon the witnesses in this sort of

32 [2004] EWCA Crim 1441.

33 see Para 19.

34 [2004] EWCA 1270. 
case. Secondly, the judge would have to make his decision at a time when there would be obvious pressure on him to allow the case to continue.

Finally, Lord Lane's test as to the burden and standard of proof in establishing abuse has come under scrutiny. In $R v E W^{35}$ Clarke LJ said:

It appears to us that ultimately the question for the judge on any application for a stay in a case of this kind is essentially whether in all the circumstances of the case a fair trial is possible notwithstanding the delay. We think there is force in the point that once the issue has been raised it must be for the Crown to satisfy the court that a fair trial is still possible. Nevertheless it must be for the defendant to raise the issue and to identify those respects in which he says that a fair trial is not possible.

This judgment was quoted with approval by Rose LJ in $R v$ Pauls $^{36}$ where he said at para 20:

"In our judgment the discretionary decision whether or not to grant a stay as an abuse of process because of delay, is an exercise of judicial assessment dependent on judgment rather than any conclusion as to fact based on evidence. It is therefore potentially misleading to apply to the exercise of that discretion the language of burden and standard of proof, which is more apt to an evidence based fact finding process. Accordingly we doubt whether today, in the light of intervening authorities in relation to the exercise of judicial discretion, Lord Lane would have expressed himself as he did with regard to the burden and standard of proof."

Lord Rose went on to stress that his remarks, and those of Clarke LJ, represented no departure from the general approach of Lord Lane and he reiterated that a stay should only be granted in exceptional circumstances.

However, it can be argued that the judgments in $R v$ Pauls and $R v E W$ certainly represent a change of emphasis, encouraging a trial judge to exercise his discretion in deciding whether a defendant can have a fair trial rather than leaving the burden on the defendant to prove a negative, albeit on a balance of probabilities. 


\section{BECKFORD AND BEYOND}

As can be seen from this article, cases on abuse of process show no sign of abating and the doctrine will continue to develop. There are two recurrent themes in this development, both of which have been traced in this article. The first is that this area of law, so vital in striking a balance between the need to bring criminals to justice and the right to fair trial, is essentially judge-made law. The judges are exercising their inherent powers to stay prosecutions which are vexatious or oppressive. Such inherent power is a vital part of our unwritten constitution and needs to be jealously guarded.

The second is that in deciding whether or not to stay proceedings, the emphasis for trial judges is upon the exercise of judicial discretion in deciding what is fair and just in the instant case.

Lord Denning would surely have approved of these two propositions. 